\title{
Historic photographs of glaciers and glacial landforms from the Ralph Stockman Tarr collection at Cornell University
}

\author{
Julie Elliott $^{1}$ and Matthew E. Pritchard ${ }^{2}$ \\ ${ }^{1}$ Department of Earth, Atmospheric, and Planetary Sciences, Purdue University, \\ West Lafayette, IN 47907, USA \\ ${ }^{2}$ Department of Earth and Atmospheric Sciences, Cornell University, Ithaca, NY 14850, USA \\ Correspondence: Julie Elliott (julieelliott@purdue.edu)
}

Received: 8 March 2019 - Discussion started: 25 June 2019

Revised: 29 November 2019 - Accepted: 4 December 2019 - Published: 2 April 2020

\begin{abstract}
Historic photographs are useful for documenting glacier, environmental, and landscape change, and we have digitized a collection of about 1949 images collected during an 1896 expedition to Greenland and trips to Alaska in 1905, 1906, 1909, and 1911, led by Ralph Stockman Tarr and his students at Cornell University. These images are openly available in the public domain through Cornell University Library (http://digital.library.cornell.edu/collections/tarr, last access: 15 March 2020; Tarr and Cornell University Library, 2014, https://doi.org/10.7298/X4M61H5R). The primary research targets of these expeditions were glaciers (there are about 990 photographs of at least 58 named glaciers), but there are also photographs of people, villages, and geomorphological features, including glacial features in the formally glaciated regions of New York state. Some of the glaciers featured in the photographs have retreated significantly in the last century or even completely vanished. The images document terminus positions and ice elevations for many of the glaciers and some glaciers have photographs from multiple viewpoints that may be suitable for ice volume estimation through photogrammetric methods. While some of these photographs have been used in publications in the early 20th century, most of the images are only now widely available for the first time. The digitized collection also includes about 300 lantern slides made from the expedition photographs and other related images and used in classes and public presentations for decades. The archive is searchable by a variety of terms including title, landform type, glacier name, location, and date. The images are of scientific interest for understanding glacier and ecological change; of public policy interest for documenting climate change; of historic and anthropological interest as local people, settlements, and gold-rush era paraphernalia are featured in the images; and of technological interest as the photographic techniques used were cutting edge for their time.
\end{abstract}

In recent decades, glacier retreat has become symbolic of climate change, but the relationship between climate and glacier response is complex. While global trends indicate significant ice loss throughout the 20th and early 21 st centuries, glaciers are not losing ice at the same rate and a small fraction are continuing to gain mass (e.g., Larsen et al., 2007, 2015; Hill et al., 2018). A variety of factors control whether an individual glacier is advancing or retreating and how it will respond to regional climate change (e.g., Post et al., 2011; Larsen et al., 2015). To better understand the link between climate and glacier behavior, long-term records beyond the relatively short temporal limits of satellite observations are essential. Historic photographs can significantly expand the time span of observations, leading to both qualitative and quantitative evaluations of glacier fluctuations and their possible causes (e.g., Molnia, 2007; Bjørk et al., 2012). In recent years, historic photographs have been used in applications as diverse as studies of human history in Glacier 
Bay, Alaska; television documentaries; and education materials (e.g., Maness et al., 2017; Conner et al., 2009).

Here we describe a newly digitized collection of photographs from a series of expeditions undertaken in the late 19th and early 20th centuries to study glaciers and other geographical features in Greenland and Alaska led by Professor Ralph Stockman Tarr and his students from Cornell University. Tarr was a professor of physical geography with particular interests in glaciology and geomorphology. In pursuit of these interests, he led or participated in expeditions to western Greenland in 1896 and to various regions of Alaska and western Canada in 1905, 1906, 1909, and 1911. His former student and frequent collaborator, Lawrence Martin, joined Tarr on the expeditions of 1905, 1909, and 1911 and made trips to Alaska without Tarr in 1904, 1910, and 1913 (Tarr and Martin, 1913). The collection presented here includes images from the 1905, 1906, 1909, and 1911 expeditions and the 1896 Greenland expedition. The expeditions are discussed further below. In addition to the images from expeditions, the collection includes digitized images of lantern slides (glass slides used in magic lanterns, an early version of a projector) that were used in teaching at Cornell and public lectures. These lantern slides duplicate a few of the original images from the expeditions but also include images from other scientific expeditions as well from commercial teaching collections. A summary of the digitized collection is shown in Table 1. Approximate image locations are shown in Figs. 1 and 2 (Alaska) and Fig. 3 (Greenland).

Counting the expedition images and lantern slides together, there are images of at least 50 named glaciers in Alaska and eight in Greenland in the collection (Tables 2 and 3 ). The glaciers featured in these images are of global importance as glaciers in coastal Greenland and Alaska are significant contributors to current sea-level rise because of their rapid loss of ice mass (e.g., Gardner et al., 2013). Of these 58 glaciers, 35 have photos that clearly show the majority of their terminus, which will allow the position to be mapped and compared to modern terminus positions. Roughly half of the glaciers have images in which the vertical extent of ice is easily distinguished against valley walls and other features that can serve as benchmarks for modern comparisons. Eight of the glaciers in Alaska have photographs of the terminus region taken from at least three different viewpoints, which may make the images suitable for ice volume estimation through photogrammetric methods. About $20 \%$ of the glaciers, either through single photographs or a combination of photographs, have imagery covering at least $5 \mathrm{~km}$ of their length, measured from their terminus. Tables 2 and 3 list which glaciers fall into each of these categories.

In addition to the glaciers themselves, Tarr was very interested in the landforms formed and left behind by the glaciers. The collection includes images of alluvial fans, various types of moraines, outwash plains, eskers, kettles, fosse, and other glacial features (Fig. 4). In Alaska and Greenland, the images show active and recently active features.
The collection also includes images of features developed during the last glacial maximum in the Finger Lakes region of upstate New York. Moraines are the most frequently featured glacier landforms in the images. In many images, the moraine appears alongside other features, such as mountains or shorelines, that are easily located in modern maps and imagery. This is especially true in Alaska, where moraine locations in images from Prince William Sound (Columbia, Spencer, and Shoup glaciers), the Wrangell Mountains (Kennicott Glacier), and the Yakutat Bay/Russell Fjord region (Hubbard, Orange, Hidden, Variegated, Atrevida, and Hidden glaciers) can be mapped and compared to present-day landscapes. Other types of geological changes are also documented in these photographs. One goal of the expeditions to Alaska was to document changes caused by a series of earthquakes in the area (e.g., Tarr, 1909; Martin, 1910; Tarr and Martin, 1912a) that caused significant, abrupt uplift and subsidence (Fig. 5). These observations have been used in modern tectonic studies (Plafker and Thatcher, 2008) and can be useful in separating instantaneous tectonic motion from the effects of glacial isostatic adjustment that have accumulated over the past century. For all of the regions Tarr visited, the collection includes images of people, towns, and smaller settlements that provide a glimpse into life at the turn of the 20th century (in particular, gold-rush era Interior Alaska, the Yukon, and British Columbia).

Historic photographs have been used for decades to observe glacier change (e.g., Molnia, 2007, 2008; Meier et al., 1985), but the digitized photographs described here are a significant addition as they have been little studied and include glaciers with few historic photographs. Although most of the photographs in this collection have been publically available in the Division of Rare and Manuscript Collections (RMC) of the Cornell University Library for decades, only a fraction have been published in articles (e.g., Tarr and Martin, 1914). In particular, photographs from the 1911 expedition were not used extensively in publications (although see, e.g., Tarr and Martin, 1912b, 1913; Martin 1913a), because Tarr died suddenly in March, 1912, at age 48 and the collaborators moved on to other projects (e.g., Brice, 1985, 1989). Thus, many of the photographs have not been otherwise published or catalogued and have been seldom viewed over the past 100 years.

In the following sections, we describe the purposes and context of the expeditions, the types of photographs and the subjects, and how they were digitized.

\section{The expeditions and photography}

\subsection{Photographers and equipment}

The photographs were taken by a variety of photographers. Tarr and Martin both took photographs. During the 1906 and 1909 expeditions, many of the photos were taken by Oscar D. von Engeln. A keen photographer, von Engeln worked with Tarr as an undergraduate and graduate student at Cor- 
Table 1. Summary of digitized photographs.

\begin{tabular}{lll}
\hline Expedition/year & $\begin{array}{l}\text { Approximate } \\
\text { number of } \\
\text { photos }\end{array}$ & Examples of key geographic locations \\
\hline 1896 & 374 & $\begin{array}{l}\text { Labrador and Baffin Land, Canada; Nugsuak (Nuussuaq) Peninsula, } \\
\text { Waigat (Vaigat/Sullorsuaq) Strait, Disko Island, and Umenak } \\
\text { (Umanak/Uummannaq) Fjord, Greenland }\end{array}$ \\
\hline 1905 & 198 & Yakutat Bay and steamer ride from Seattle \\
\hline 1906 & 264 & Yakutat Bay and steamer ride from Seattle \\
\hline 1909 & 582 & $\begin{array}{l}\text { Yakutat Bay, eastern Prince William Sound, Kenai Peninsula, lower } \\
\text { Copper River, coastal southeast Alaska, Inside Passage to Seattle }\end{array}$ \\
\hline 1911 & 356 & $\begin{array}{l}\text { Prince William Sound, Kenai Peninsula, Wrangell Mountains, } \\
\text { Interior Alaska (including Fairbanks and several mining towns), } \\
\text { Yukon Territory, northern British Columbia, Glacier Bay, Inside } \\
\text { Passage to Seattle }\end{array}$ \\
\hline Lantern slides/various years & 308 & Alaska, Canada, Greenland, Antarctica \\
\hline Ithaca/1888-1928 & 54 & Waterfalls and glacial landforms around Ithaca, New York \\
\hline
\end{tabular}

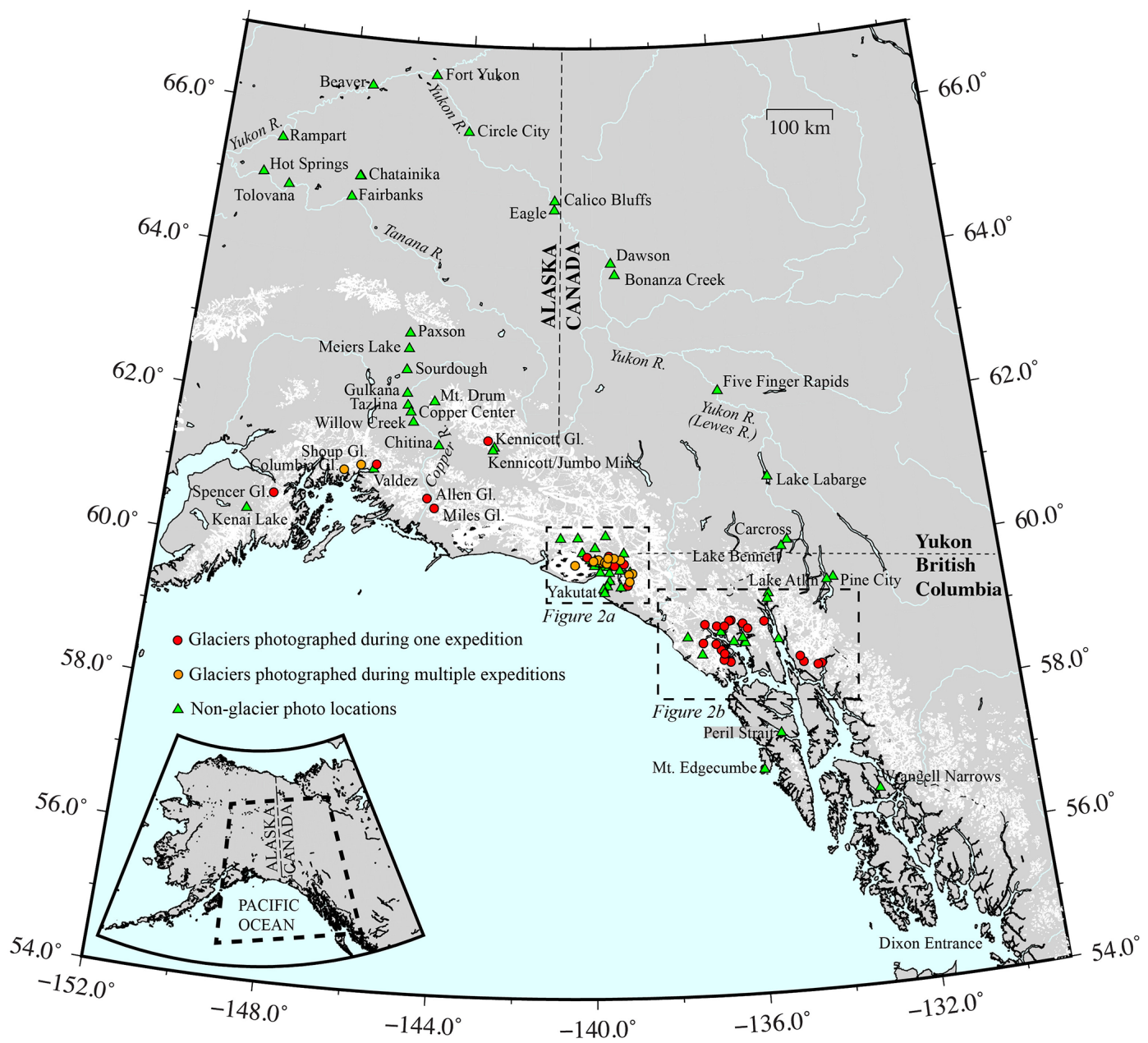

Figure 1. Locations visited during expeditions to Alaska between 1905 and 1911. 
Table 2. Alaska glacier photographs in collection.

\begin{tabular}{|c|c|c|c|c|c|c|}
\hline Glacier & Region & $\begin{array}{l}\text { Years of photos } \\
\text { in collection }\end{array}$ & $\begin{array}{r}\text { No. of photos } \\
\text { in collection }\end{array}$ & $\begin{array}{c}\text { No. of photos } \\
\text { of terminus }\end{array}$ & $\begin{array}{l}\text { Multiple } \\
\text { viewpoints }\end{array}$ & $\begin{array}{l}\text { Large } \\
\text { area }^{h}\end{array}$ \\
\hline Columbia & Prince William Sound & 1909,1911 & 79 & 12 & Yes & Yes \\
\hline Spencer & Prince William Sound & 1911 & 40 & 5 & No & No \\
\hline Shoup & Prince William Sound & 1909,1911 & 33 & 6 & Yes & Yes \\
\hline Valdez & Prince William Sound & 1909 & 30 & 5 & No & No \\
\hline Catspaw $^{\mathrm{a}}$ & Prince William Sound & 1909 & 1 & - & - & - \\
\hline Miles & Chugach Mts. & 1909 & 17 & 4 & No & No \\
\hline Allen $\left(\right.$ Baird) ${ }^{\mathrm{b}}$ & Chugach Mts. & 1909 & 13 & - & - & - \\
\hline Kennicott & Wrangell Mts. & 1911 & 15 & - & - & Yes \\
\hline Hubbard & Yakutat & 1905, 1906, 1909 & 105 & 28 & Yes & Yes \\
\hline Turner & Yakutat & 1905, 1906, 1909 & 66 & 16 & Yes & No \\
\hline Haenke & Yakutat & 1906 & 1 & 1 & No & Yes \\
\hline Galiano & Yakutat & 1905, 1906, 1909 & 16 & - & - & - \\
\hline Atrevida & Yakutat & 1905, 1906, 1909 & 51 & 2 & No & Yes \\
\hline Variegated & Yakutat & 1905, 1906, 1909 & 44 & 4 & No & No \\
\hline Cascading & Yakutat & 1905, 1906, 1909 & 6 & - & - & - \\
\hline Nunatak & Yakutat & 1905, 1906, 1909 & 82 & 28 & Yes & Yes \\
\hline Hayden & Yakutat & 1905, 1906, 1909 & 27 & - & - & - \\
\hline Malaspina & Yakutat & 1905, 1906, 1909 & 24 & 2 & No & Yes \\
\hline Lucia & Yakutat & 1905, 1906, 1909 & 30 & 5 & No & Yes \\
\hline Hidden & Yakutat & 1905, 1906, 1909 & 79 & 26 & Yes & Yes \\
\hline Marvine & Yakutat & 1906 & 31 & - & - & - \\
\hline Alexander & Yakutat & 1906 & 1 & - & - & - \\
\hline Orange & Yakutat & 1906 & 7 & 1 & No & No \\
\hline Fourth (Beasley) ${ }^{\mathrm{c}}$ & Yakutat & 1909 & 18 & 5 & Yes & No \\
\hline Black & Yakutat & 1905,1909 & 2 & - & - & - \\
\hline Haenke & Yakutat & 1909 & 4 & 2 & No & No \\
\hline Flat $^{\mathrm{a}}$ & Yakutat & 1905 & 4 & - & - & - \\
\hline Serpentine $^{a}$ & Yakutat & 1905 & 3 & - & - & - \\
\hline Fallen $^{\mathrm{d}}$ & Yakutat & 1905 & 1 & - & - & - \\
\hline Muir & Glacier Bay & 1911 & 28 & 6 & Yes & Yes \\
\hline McBride & Glacier Bay & 1911 & 4 & 1 & No & No \\
\hline Casement & Glacier Bay & 1911 & 1 & - & - & - \\
\hline Morse & Glacier Bay & 1911 & 1 & 1 & No & No \\
\hline Rendu & Glacier Bay & 1911 & 11 & 4 & No & No \\
\hline Wood & Glacier Bay & 1911 & 2 & 2 & No & No \\
\hline Davidson & Glacier Bay & 1911 & 4 & 2 & No & No \\
\hline Hugh Miller & Glacier Bay & 1911 & 8 & 3 & No & No \\
\hline Carroll & Glacier Bay & 1911 & 3 & 2 & No & No \\
\hline Grand Pacific & Glacier Bay & 1911 & 2 & 2 & No & No \\
\hline Johns Hopkins & Glacier Bay & 1911 & 3 & - & - & - \\
\hline Reid & Glacier Bay & 1911 & 2 & 2 & No & No \\
\hline Charpentier & Glacier Bay & 1911 & 6 & 3 & No & No \\
\hline Geikie & Glacier Bay & 1911 & 2 & 1 & No & No \\
\hline White $\mathrm{e}^{\mathrm{e}}$ & Glacier Bay & Not listed & 1 & 1 & No & No \\
\hline Favorite & Glacier Bay & 1911 & 3 & - & - & - \\
\hline Girdled $^{\mathrm{e}}$ & Glacier Bay & Not listed & 1 & & & \\
\hline Taku & Juneau & 1911 & 7 & 4 & No & No \\
\hline Norris & Juneau & 1911 & 3 & - & - & - \\
\hline Herbert & Juneau & 1911 & 1 & - & - & - \\
\hline Mendenhall & Juneau & 1911 & 1 & - & - & - \\
\hline
\end{tabular}

${ }^{a}$ Location and identification uncertain. ${ }^{b}$ Tarr referred to this glacier as Baird; the later accepted name is Allen. ${ }^{c}$ Tarr used both names for this glacier in the photos; the accepted name is Fourth. ${ }^{\mathrm{d}}$ Tarr and Martin (1914) reported that this glacier slid into the Disenchantment Bay on 4 July 1905, causing a local tsunami. ${ }^{\mathrm{e}}$ Glacier only appears in a photo by H. Reid on a lantern slide. ${ }^{\mathrm{f}}$ To be counted in this category, the photo had to show the majority of the terminus region. ${ }^{\mathrm{g}}$ At least three viewpoints of the terminus region (e.g., front view and angled from each side). ${ }^{\mathrm{h}}$ Photos (either as a single photo or collectively) show at least $5 \mathrm{~km}$ of the glacier from the terminus region. 


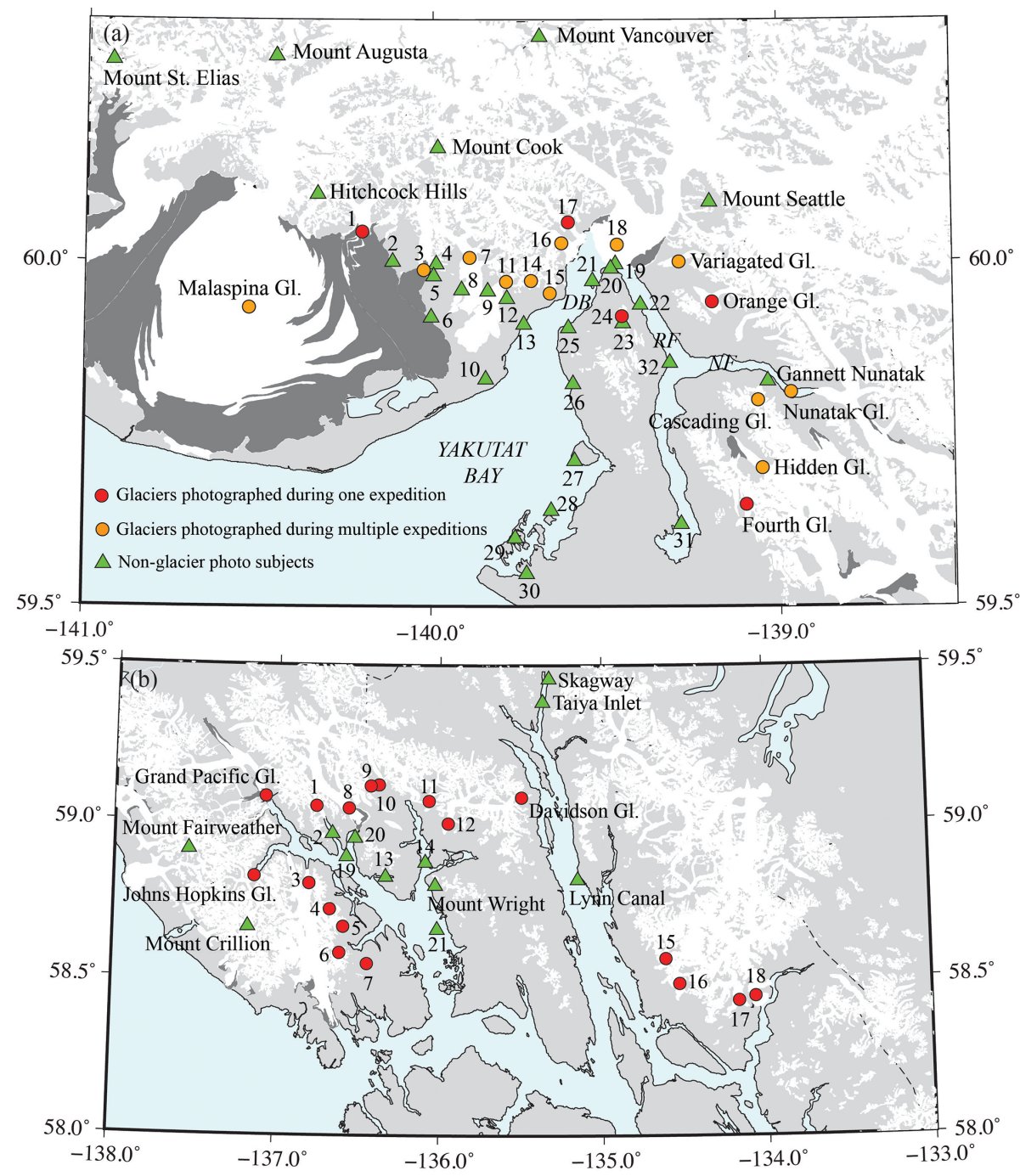

Figure 2. Sites visited in southeast Alaska. (a) Sites visited in Yakutat Bay. DB is Disenchantment Bay, RF is Russell Fjord, and NF is Nunatak Fjord. Numbered locations are (1) Marvine Gl., (2) Blossom Island, (3) Hayden Gl., (4) Floral Hills, (5) Floral Pass, (6) Kwik Stream, (7) Lucia Gl., (8) Lucia Stream, (9) Terrace Point, (10) Strawberry Island, (11) Atrevida Gl., (12) Ampitheater Knob, (13) Esker Stream, (14) Galianao Gl., (15) Black Gl., (16) Turner Gl., (17) Haenke Gl., (18) Hubbard Gl., (19) Osier Island, (20) Gilbert Point, (21) Haenke Island, (22) Marble Point, (23) Mt. Alexander, (24) Alexander Gl., (25) Indian Camp, (26) Logan Beach, (27) Knight Island, (28) Otmeloi Island, (29) Khantaak Island, (30) Yakutat, (31) Cape Stoss, and (32) Cape Enchantment. (b) Sites visited in Glacier Bay. Numbered locations are (1) Rendu Gl., (2) Rendu Inlet, (3) Reid Gl., (4) Hugh Miller Gl., (5) Charpentier Gl., (6) Geike Gl., (7) Wood Gl., (8) Carroll Gl., (9) Morse Gl., (10) Muir Gl., (11) McBride Gl., (12) Casement Gl., (13) Tidal Inlet, (14) Muir Inlet, (15) Herbert Gl., (16) Mendenhall Gl., (17) Norris Gl., (18) Taku Gl., (19) Russell Island, (20) Triangle Island, and (21) N. Marble Island.

nell and later became a professor in the Department of Geology and Geography there. James Otis Martin, a Cornell student who accompanied Tarr to Greenland in 1896, took a number of the photographs during that expedition (Tarr, 1897a-i). Photos in the collection were also taken by members of the U.S. Geological Survey (USGS), engineers of the Copper River and Northwestern Railway, members of the Canadian Boundary Survey, and several unnamed Alaskan photographers (Tarr and Martin, 1914). The lantern slides include photos taken by members of other well-known expedi- tions, including William Libbey, a Princeton geographer who participated in a trip to explore Mount St. Elias in Alaska in 1886, Peary's 1894 expedition to Greenland, and a 1899 Princeton-funded trip to Greenland (Koelsch, 2016); F. Jay Haynes, a professional photographer who visited Alaska, Yellowstone, and other parts of the American West; Henry Fielding Reid, a professor at Johns Hopkins who performed pioneering studies of glacier dynamics in southeast Alaska in addition to groundbreaking work on how faults related to earthquakes; and Israel Russell, a USGS scientist who ex- 


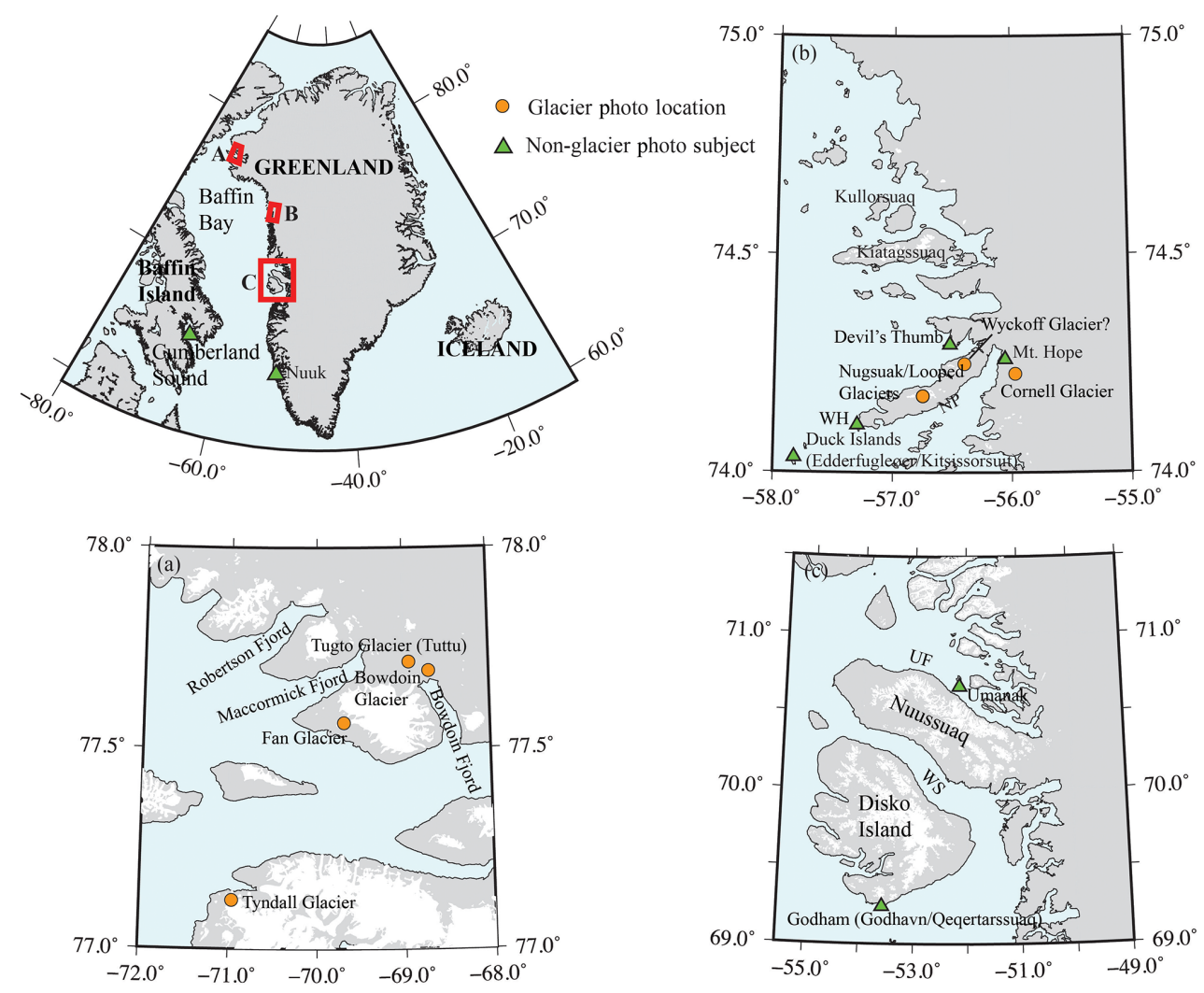

Figure 3. Sites visited in Greenland. (a) Site locations in the Qaanaaq region. (b) Site locations in the Upernavik Archipelago region. WH is Wilcox Head and NP is Nugsauk (Nuussuaq) Peninsula. (c) Site locations in the Disko Bay region. UF is Umenak (Umanak/Uummannaq) Fjord. WS is Waigat (Vaigat/Sullorsuaq) Strait.

plored the regions of Mount St. Elias and Yakutat Bay in Alaska.

Equipment varied depending on the trip and the most detail is known about the equipment used in the 1906 and 1909 Alaska expeditions as von Engeln published articles on techniques he used to take and develop photographs in the challenging field conditions (von Engeln, 1907b, 1910). During those expeditions, he used a Rochester Optical Company Pony Premo self-casing folding plate camera (which is preserved in the Cornell RMC; see Fig. 6a and b) as well as several other cameras including multiple Kodak film cameras (von Engeln, 1907b). Exposures were made on glass plates and film negatives (typically standard $4 \mathrm{in} . \times 5 \mathrm{in}$. size, with a few of larger size). Several lenses were used, including a long-focus lens that was custom-made by Bauch and Lomb for the Alaska work (von Engeln, 1907b). At least one camera had a mount system that allowed the capture of panoramic images on film (Fig. 6e, f). As shown in Fig. 6c-e, some of the images capture the process and difficulty of taking photographs in the rugged field environment. The cameras, lenses, shutter, and plate holders were packed into a leather case with straps so that it could be more easily carried along with a tripod, plates and film, and containers for changing plates and protecting exposed film from the excessive humidity of southeast Alaska (von Engeln, 1907b). Although the camera system was designed to be compact, setting it up and making the exposures often took considerably more time than scientific observations and notes at a site (von Engeln, 1910).

\subsection{The expeditions}

We briefly describe the expeditions that are summarized in Table 1 and Figs. 1, 2, and 3.

\subsubsection{Greenland}

In 1896, Tarr, along with other faculty and students from Cornell, traveled to Greenland as part of Robert Peary's expedition that attempted (and failed) to remove the largest of the three Cape York meteorites (Tarr, 1896; Huntington, 2002). The Cornell group was one of three scientific parties along on the expedition; after stops along the coast of Labrador and at Baffin Island, Disko Island, Waigat (Vaigat or Sullorsuaq) Strait, and Umanak (Uummannaq), they were landed on the Nugsuak (Nuussuaq) Peninsula along the Upernavik Archipelago (Fig. 3) where they stayed for several weeks 
Table 3. Greenland glacier photographs in collection.

\begin{tabular}{|c|c|c|c|c|c|c|}
\hline Glacier $^{\mathrm{a}}$ & Region & $\begin{array}{l}\text { Year of } \\
\text { photos }\end{array}$ & $\begin{array}{l}\text { No. of } \\
\text { photos }\end{array}$ & $\begin{array}{l}\text { No. of photos } \\
\text { of terminus }\end{array}$ & $\begin{array}{l}\text { Multiple } \\
\text { viewpoints }\end{array}$ & $\begin{array}{l}\text { Large } \\
\text { area }^{f}\end{array}$ \\
\hline Cornell (Ikissuup Sermersua) & $\begin{array}{l}\text { Nuussuaq Peninsula - } \\
\text { Upernavik Archipelago }\end{array}$ & 1896 & 88 & 11 & No & No \\
\hline Wyckoff & $\begin{array}{l}\text { Nuusssuaq Peninsula - } \\
\text { Upernavik Archipelago }\end{array}$ & 1896 & 3 & - & - & - \\
\hline $\operatorname{Nugsuak}^{\mathrm{b}}$ (Sermikavsak?) & $\begin{array}{l}\text { Nuussuaq Peninsula - } \\
\text { Upernavik Archipelago }\end{array}$ & 1896 & 12 & - & - & - \\
\hline Bowdoin $^{c}$ (Kangerluarsuup Sermia) & Qaanaaq & 1894 or 1899 & 10 & 1 & No & Yes \\
\hline Tuktoo (Tugto) ${ }^{\mathrm{c}}($ Tuttu) & Qaanaaq & 1894 or 1899 & 1 & - & - & - \\
\hline $\operatorname{Fan}^{\mathrm{c}}($ Fan $)$ & Qaanaaq & 1894 or 1899 & 1 & - & - & - \\
\hline Robertson ${ }^{\mathrm{c}}$ & Qaanaaq & 1894 or 1899 & 1 & 1 & No & No \\
\hline Tyndall $^{\mathrm{c}}$ (Tyndall) & Qaanaaq & 1894 or 1899 & 1 & 1 & No & No \\
\hline
\end{tabular}

a Regular type gives name of glacier as known to the photographer at the time the image was acquired; italic type gives Greenlandic name or name it is commonly known as today. ${ }^{b}$ Variably spelled as Nugsuak or Nugssuak in collection materials. ${ }^{c}$ Only appears as photos by Libbey on lantern slides. ${ }^{\mathrm{d}}$ To be counted in this category, the photo had to show the majority of the terminus region. ${ }^{\mathrm{e}}$ At least three viewpoints of the terminus region (e.g., front view and angled from each side). ${ }^{\mathrm{f}}$ Photos (either as a single photo or collectively) show at least $5 \mathrm{~km}$ of the glacier from the terminus region.

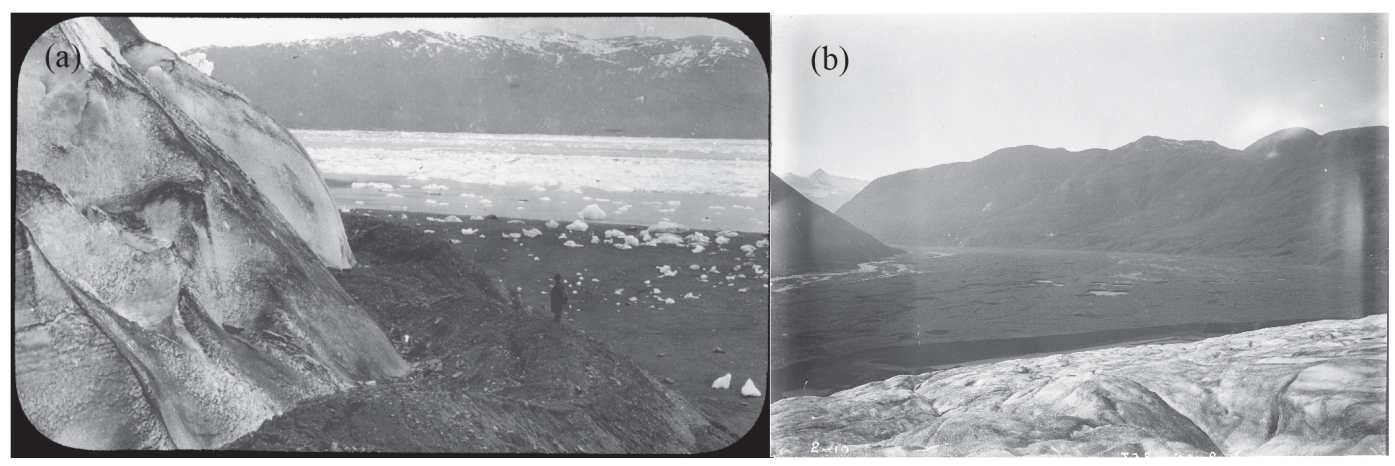

Figure 4. Examples of photographs of glacial features. (a) Push moraine at the front of Columbia Glacier (note person for scale) (ID: tve_lanternslide_0004). (b) Kettles in outwash plain of Hidden Glacier (ID: tve_exp1905_162).

making studies of the geology, plant life, birds, and invertebrates (Tarr, 1896). While there, they described and assigned names to a number of geographic features including Cornell Glacier, Wyckoff Glacier (after an Ithaca businessman who provided financial backing for the expedition), and Mt. Schurman (after the President of Cornell University) (e.g., Tarr, 1896, 1897a, b). Tarr wrote extensively of his field observations on the trip (Tarr, 1896, 1897a-i). The digitized photographs are from a variety of locations (but mostly from the Nugsuak Peninsula) and show glaciers, geological features, local people, and some of the day-to-day activities and challenges of the expedition (Fig. 7).

\subsubsection{Alaska}

In the summer of 1905, Tarr and Martin went to Yakutat Bay (Fig. 2a). Tarr was in charge of a USGS party charged with a general geological survey of the region, while Martin was funded by the American Geographical Society (e.g., Tarr and Martin, 1905). The scientific party made observations of surface changes that occurred after a series of $M 8$ earthquakes that occurred in the region in 1899 (e.g., Plafker and Thatcher, 2008), general descriptions of glaciers in the Yakutat Bay area and evidence for the extent of past glaciation, and noted the return of vegetation to areas in which glaciers had recently retreated. The work done during this trip was the primary focus of Tarr and Martin (1905) and Tarr and Martin (1906a, b, c) and featured in a number of other publications (e.g., Tarr, 1907a, b, c, d, e, 1909, 1910a, b; Tarr and Martin, 1907, 1912a, 1914). Digitized photographs from this expedition include images of the area's glaciers, faults and other features related to the 1899 earthquakes, and glacial landforms (Figs. 4 and 8).

\subsubsection{Alaska}

Tarr again led a USGS-sponsored party to Yakutat Bay in the summer of 1906. One of the party's objectives was to cross the Malaspina Glacier, but they discovered that the normally navigable tributary glaciers east of the Malaspina 


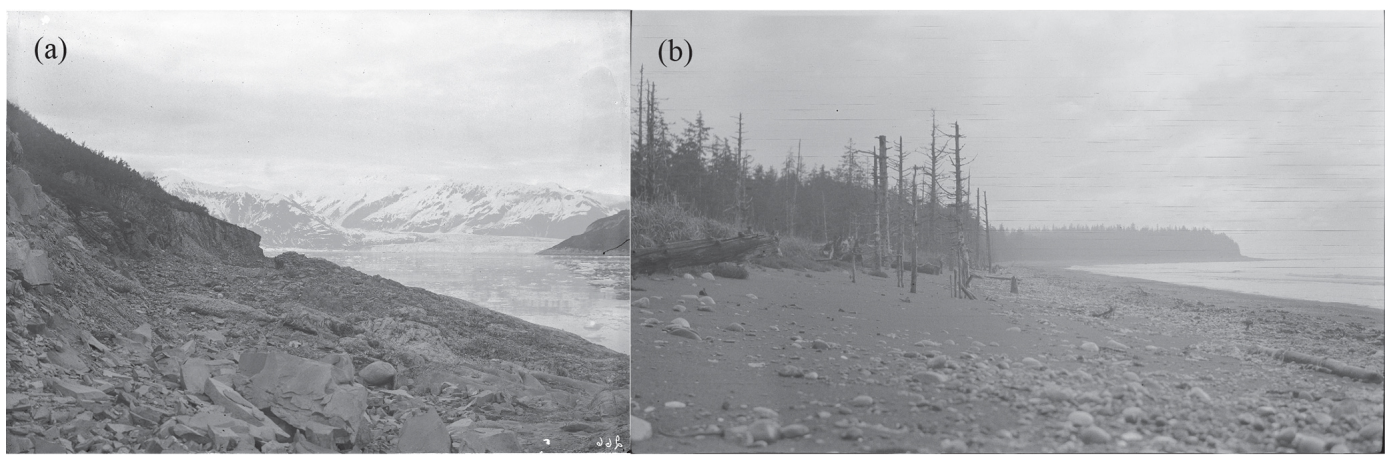

Figure 5. Photographs showing effects of 1899 earthquakes. (a) Wave-cut bench and sea cliff on east shore of Haenke Island uplifted during earthquakes (ID: tve_exp1906_183). (b) Trees on Khantaak Island killed by submergence in salt water due to earthquakes (ID: tve_exp1909_325).

had advanced and created impassable crevasse fields (Tarr, 1907d, e). At least two other glaciers in the Yakutat Bay area had also advanced since the summer of 1905 (Tarr and Martin, 1912a). Scientific findings of the expedition are described in Tarr (1907a-e, 1909, 1910a, b), Tarr and Martin (1907, 1912a, 1914), and von Engeln (1911). Popular accounts of the expedition include von Engeln (1906a, 1907a) and Alley (2012). In the collection, the 1906 digitized photos are primarily images of the glaciers along the eastern edge of the Malaspina Glacier and within Yakutat and Disenchantment bays and Russell Fjord (Fig. 9).

\subsubsection{Alaska}

With funding from the National Geographic Society, Tarr and Martin returned to Alaska with a scientific party including a dedicated photographer and topographer in 1909. Most of their time was spent in Yakutat Bay, but the group also traveled further west and made observations at Valdez, Columbia, and Shoup glaciers in eastern Prince William Sound and at Miles, Childs, and Allen glaciers along the lower Copper River (Fig. 1). The primary purposes of the trip were to make detailed maps of the glaciers of the southern Alaska coast and to make additional observations concerning the sudden advance of glaciers noted in 1906 (Tarr and Martin, 1910a). During the trip, the party found that the glacier advances noted in 1906 had slowed or stopped, while two additional glaciers around Yakutat Bay showed signs of advance. Glaciers within Prince William Sound and the Copper River did not show evidence of significant change from earlier observations (e.g., Tarr and Martin, 1910a, b). Based on these results, Tarr and Martin proposed what they referred to as the earthquake advance theory or the glacial flood hypothesis: an earthquake causes an avalanche of snow and other material onto a glacier, causing deformation that is transmitted down the glacier and eventually results in crevassing and an advance at the front of the glacier (e.g., Tarr, 1910; Tarr and Martin, 1910a). Later work in Alaska showed that the observed glacier surges are periodic and likely due to characteristics specific to the individual glacier system, not external factors such as earthquakes (e.g., Post, 1965; Meier and Post, 1969). Additional descriptions of the fieldwork and scientific work are found in Tarr and Martin (1912a, 1914) and von Engeln (1911). Within the collection, the 1909 expedition contributes more digitized images than any other trip. The images show glaciers and glacial landforms in the Yakutat Bay, Prince William Sound, and Copper River regions as well as construction camps and waypoints along the route of the Copper River Railroad (Fig. 10).

\subsubsection{Alaska}

The 1911 expedition, funded again by the National Geographic Society, was the most wide ranging of the Alaska expeditions. While Tarr, Martin, and the rest of the scientific party returned to a few previously visited sites around Prince William Sound, the overwhelming majority of locations had not been previously visited by Tarr or Martin. Members of the party spent time in Glacier Bay (Fig. 2), the Kenai Peninsula, and Prince William Sound before moving inland to the Wrangell Mountains. They then moved north into Interior Alaska, with stops at Fairbanks and other locations involved with gold mining. The group traveled up the Yukon River through Alaska and the Yukon (with a variety of stops including Dawson) before reaching the headwaters of that river in British Columbia (Fig. 1). Scientific observations are presented in Tarr and Martin (1912b, 1913). The digitized images also have the most variety of any of the expeditions: glaciers in southeast and south-central Alaska, railways, mining operations, roadhouses in Interior Alaska, city streets in Fairbanks and Dawson, and small settlements along the Yukon River (Fig. 11).

\subsubsection{Ithaca and Upstate New York}

The collection also includes images from closer to Tarr's home in Ithaca, New York. Over his 20 years at Cornell, Tarr 

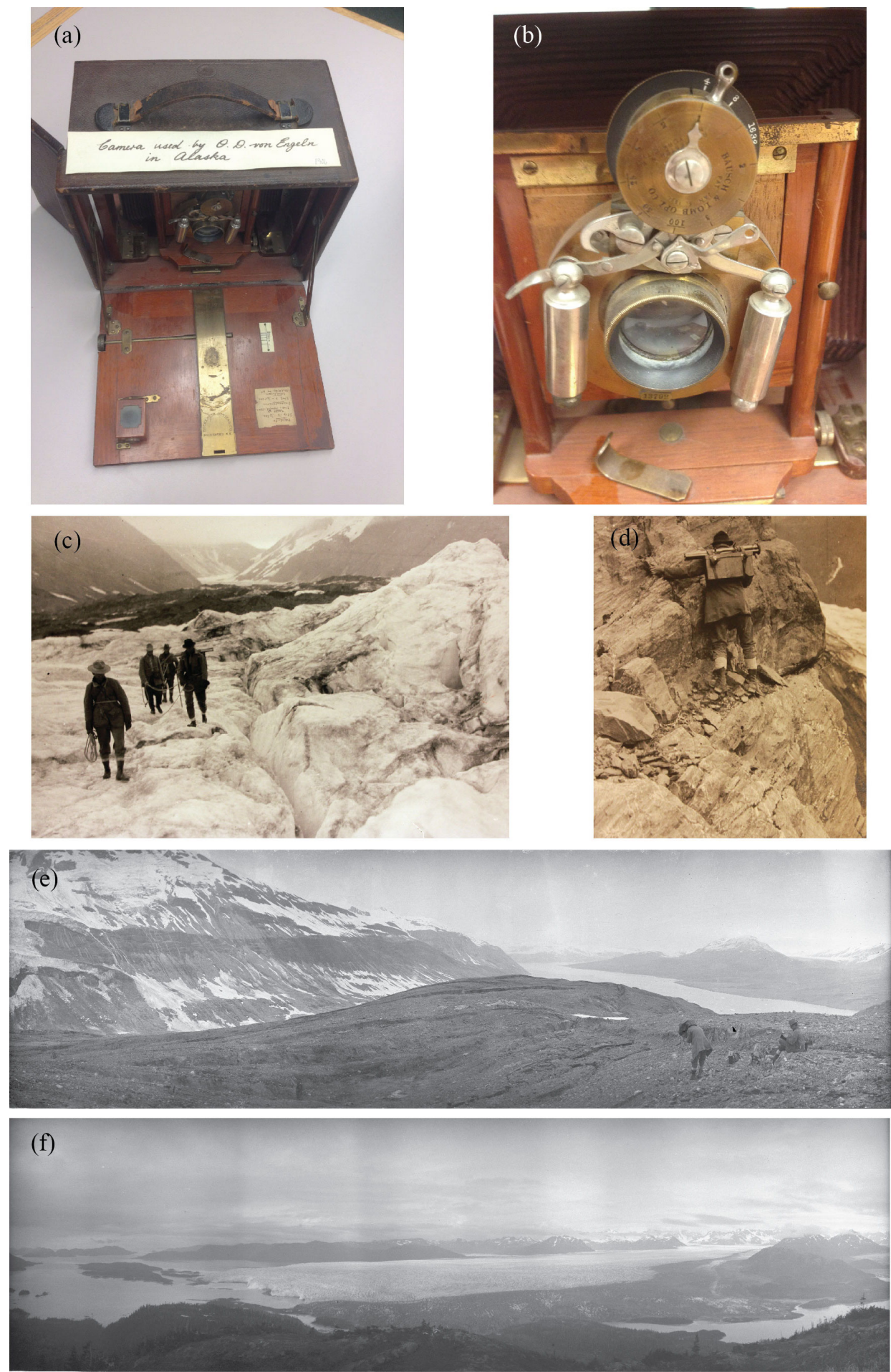

Figure 6. Equipment and field conditions. (a) Camera used in the Alaska expeditions. (b) Close-up of camera front. (c) Expedition party traversing glacier in Alaska. (d) Expedition member with photography gear traversing cliff. (e) Scientific party and camera setup, Russell Fjord, Alaska (ID: tve_exp1909_002a). (f) Example of panoramic image, Columbia Glacier, Alaska (ID: tve_exp1909_035). 

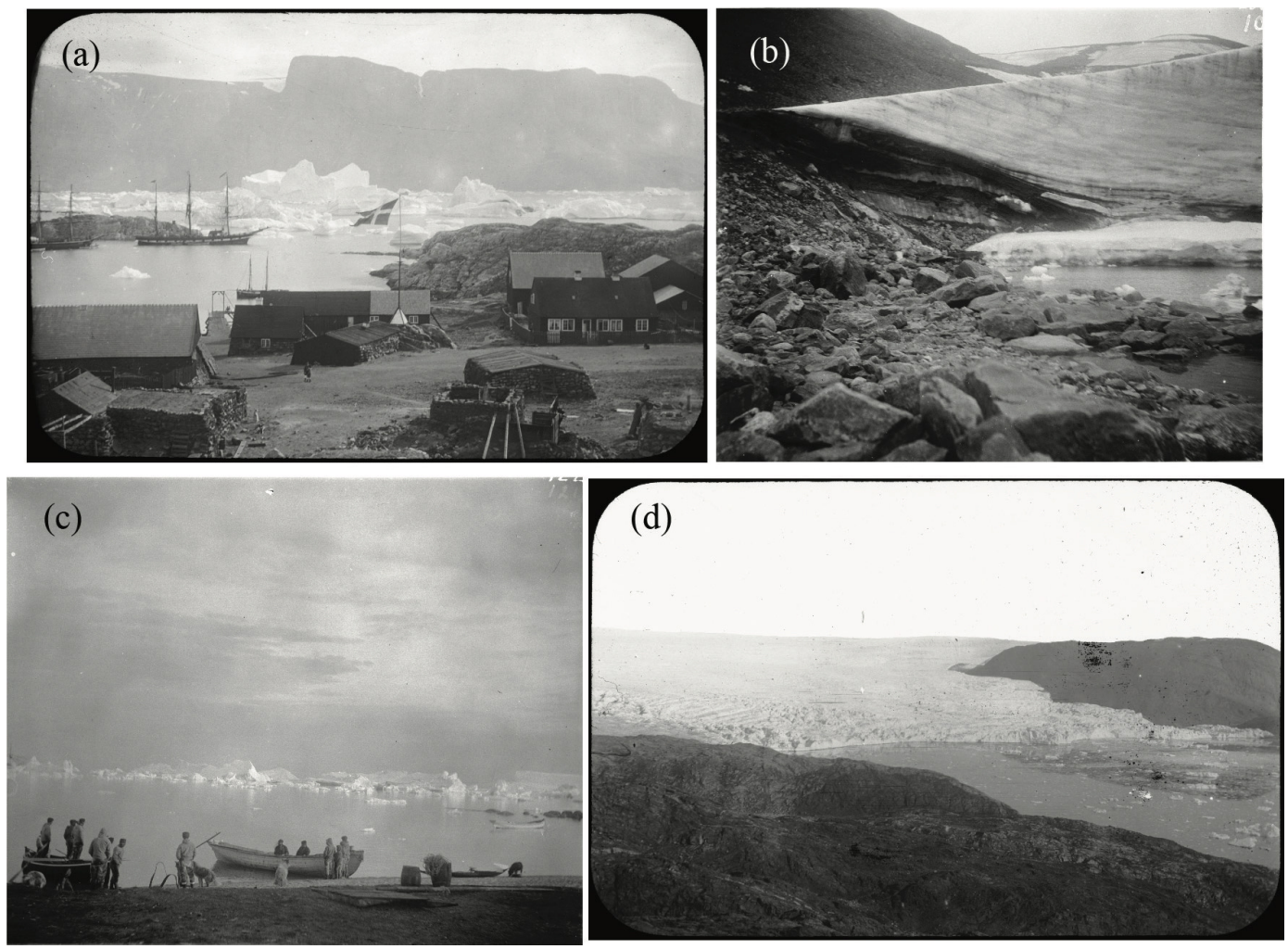

Figure 7. Digitized images from Greenland. (a) Icebergs in harbor of Umanak (Uummannaq) (ID: tve_lanternslide_0173). (b) Terminus of Nugsuak Glacier (ID: tve_exp1896_147). (c) Icebergs in Waigat Strait (ID: tve_exp1986_186). (d) North Cornell Glacier (ID: tve_lanternslide_0090).
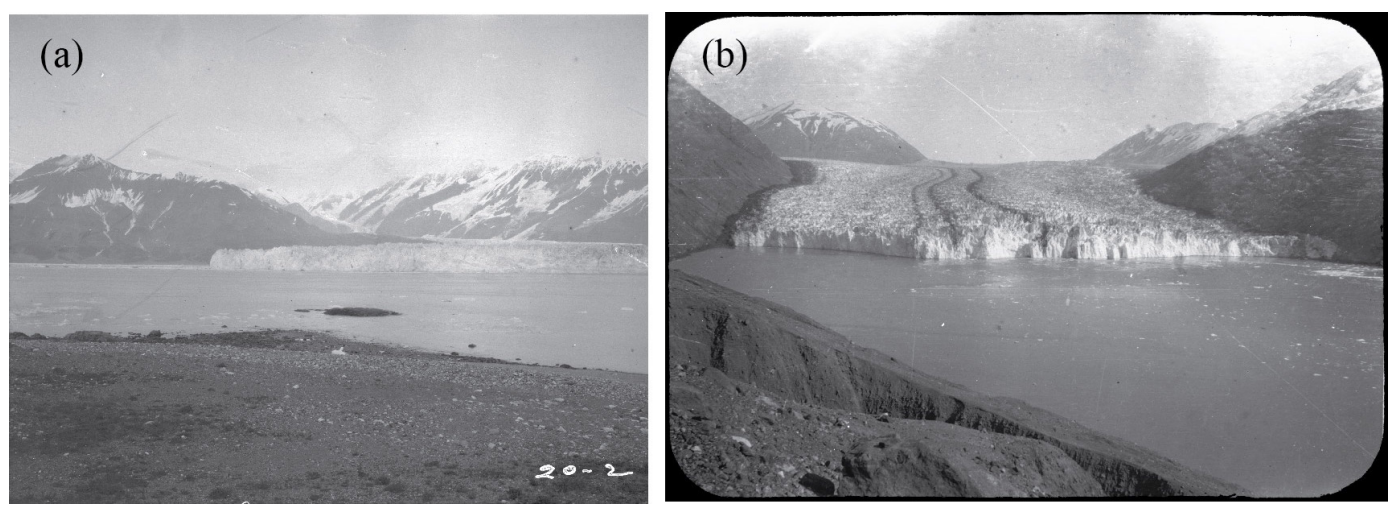

Figure 8. Digitized images from the 1905 Alaska expedition. (a) Hubbard Glacier from Osier Island (ID: tve_exp1905_100). (b) Terminus of Nunatak Glacier (ID: tve_lanternslide_0264).

accumulated images of glacial landforms and other geological features (including waterfalls) from Ithaca and upstate New York. Tarr used his observations in a number of publications on glacial erosion, the development of glacial landforms, and the geology of New York, including Tarr (1904), Tarr (1905a, b, c, d), and Tarr (1906a, b). Examples of digitized images from upstate New York are shown in Fig. 12.

\section{Description of dataset}

\subsection{Original material}

The original photographs are in the form of prints, glass plates, lantern slides, or negatives. The photographic material was placed by Tarr and his associates in individual paper envelopes with handwritten notes on the outside of the envelopes. As these envelopes were fragile due to age and not 

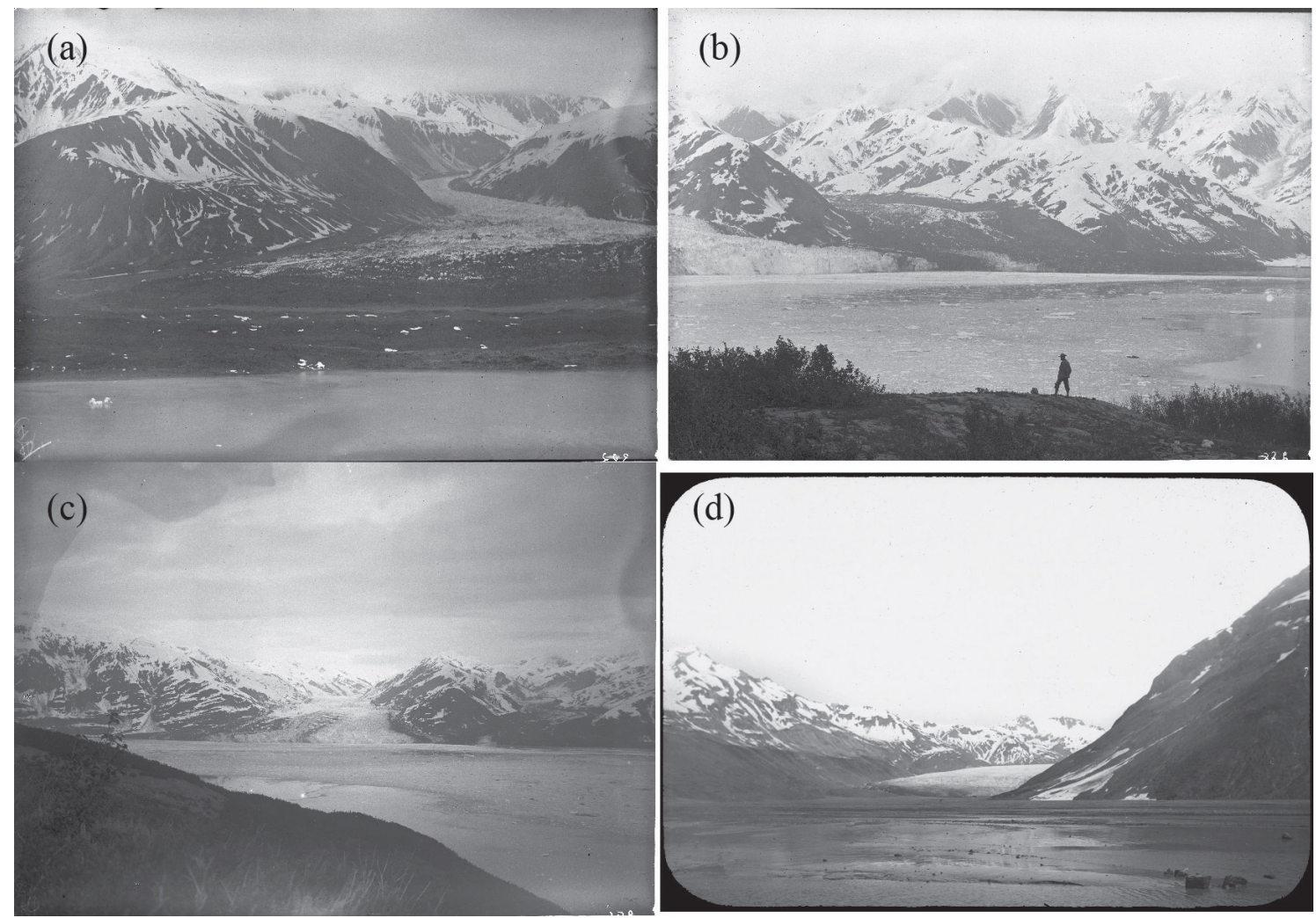

Figure 9. Digitized images from the 1906 Alaska expedition. (a) Variegated Glacier from Gilbert Point (ID: tve_exp1906_219). (b) Turner and Haenke glaciers from Haenke Island (ID: tve_exp1906_205_02). (c) Turner Glacier from Gilbert Point (ID: tve_exp1906_213). (d) Hidden Glacier and outwash plain (ID: tve_lanternslide_0267).

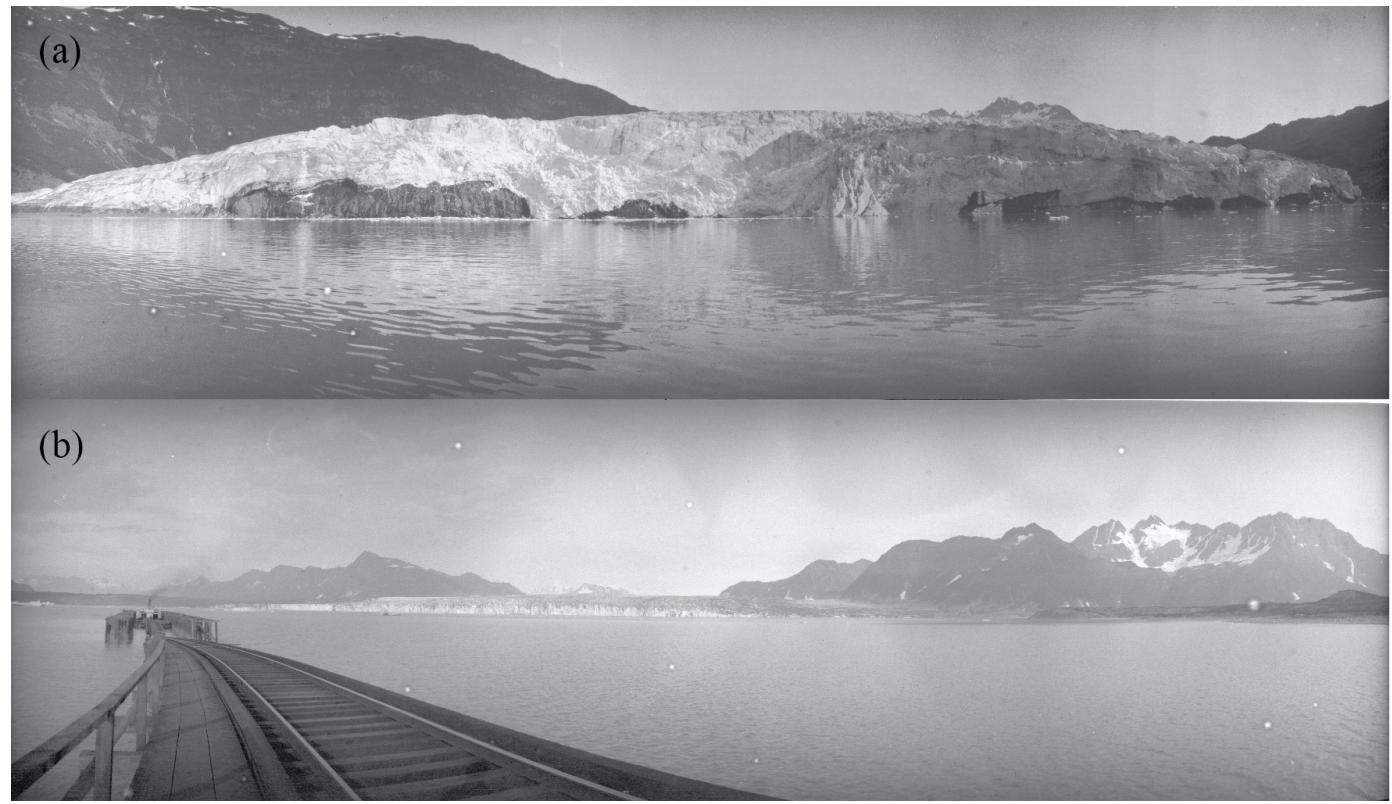

Figure 10. Digitized images from the 1909 Alaska expedition. (a) Shoup Glacier terminus (ID: tve_exp1909_032). (b) Miles Glacier and Copper River Railroad (ID: tve_exp1909_041). 

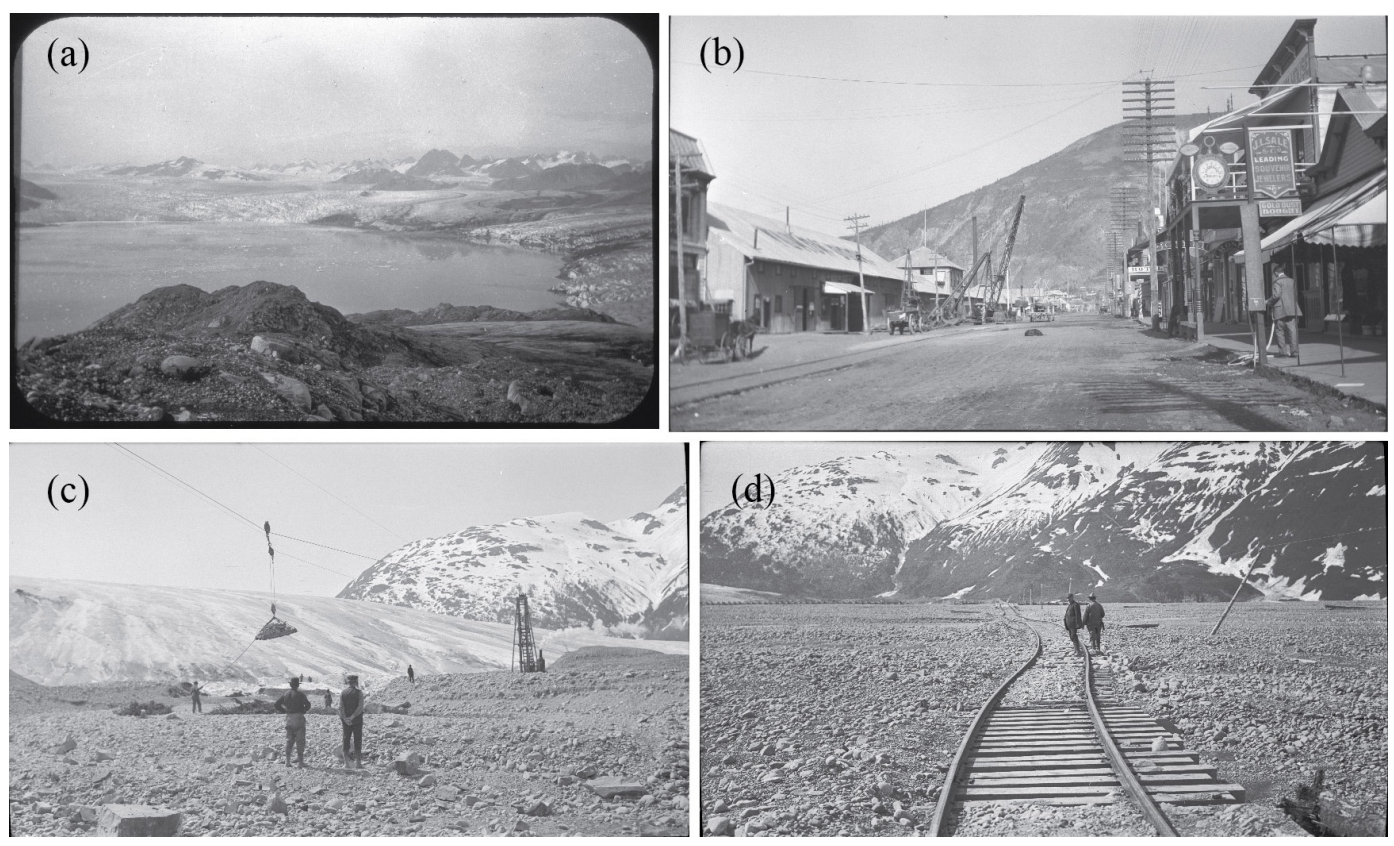

Figure 11. Digitized images from the 1911 Alaska expedition. (a) Muir Glacier (ID: tve_lanternslide_0025). (b) Street in Dawson, Yukon (ID: tve_exp1911_042). (c) Effort to build diversion dam for Spencer Glacier stream (ID: tve_exp1911_030). (d) Tracks displaced by Spencer Glacier outlet stream (ID: tve_exp1911_020).

acid-free, the materials were rehoused in acid-free paper and stored with copies of the original envelopes. These materials are stored and publically accessible through the Cornell University Library Division of Rare and Manuscript Collections as part of the Ralph Stockman Tarr papers (collection number 14-15-92, 21 boxes) and the Oscar Diedrich von Engeln papers (collection number 14-15-856, 18 boxes). Due to budget constraints, we could not digitize all of the images but focused on images of glaciers and glaciated landscapes from the Alaska and Greenland expeditions as well as the materials that would produce the highest-quality images. There are several hundred other photographs in the RMC that were not digitized along with thousands of lantern slides housed at the Department of Earth and Atmospheric Sciences at Cornell University. Not all of this material is suitable for digitization as the original materials in some cases have significantly degraded over the past century. Some of the remaining materials are prints or duplicates of already scanned material. Most of the lantern slide subjects are not directly related to the topics covered by this paper.

\subsection{Digitization}

The photographs were digitized at the Cornell University Library. Transparencies (positives, negatives, film and glass) were scanned on Epson 10000xl flatbed scanners outfitted with transparency units using custom negative holders. Scan resolution varied depending on the size of the original (900$1800 \mathrm{dpi})$. The images were scanned to $16 \mathrm{bit}$, grayscale, uncompressed TIFF files. Choosing optimal parameters for scanning was difficult as a number of the originals had degraded in quality over the years. Care was taken to capture the white and black endpoints so as not to clip those values. Curve and level adjustments were made within the scan software at the time of scanning (epsonscan software, version 3.49A). After scanning there were additional curve adjustments made in Photoshop CS6 or CC2015 (version updated during project.) Performing more of the initial curve adjustments within the scanner software reduced loss of the density range of the negatives during contrast adjustment. A few images were scanned with multiple exposures due to the poor condition of the original image material and required more than one processing version to adequately show details of different parts of the negative or glass plate. Several of the original film negatives and glass plates have been smudged or cracked over the years. In these cases, no corrective image processing has been attempted, so these artifacts appear in the digitized versions. Master images were saved as 16 bit layered tiffs with curve adjustment layers. The average file size of images in the collection is $135 \mathrm{MB}$. Uploaded access files are the full-resolution tiffs.

\subsection{Data availability}

The digitized files (original size, full-resolution tiffs) were uploaded and made available through the Cornell University Library digital collections in the collection called Historic Glacial Images of Alaska and 


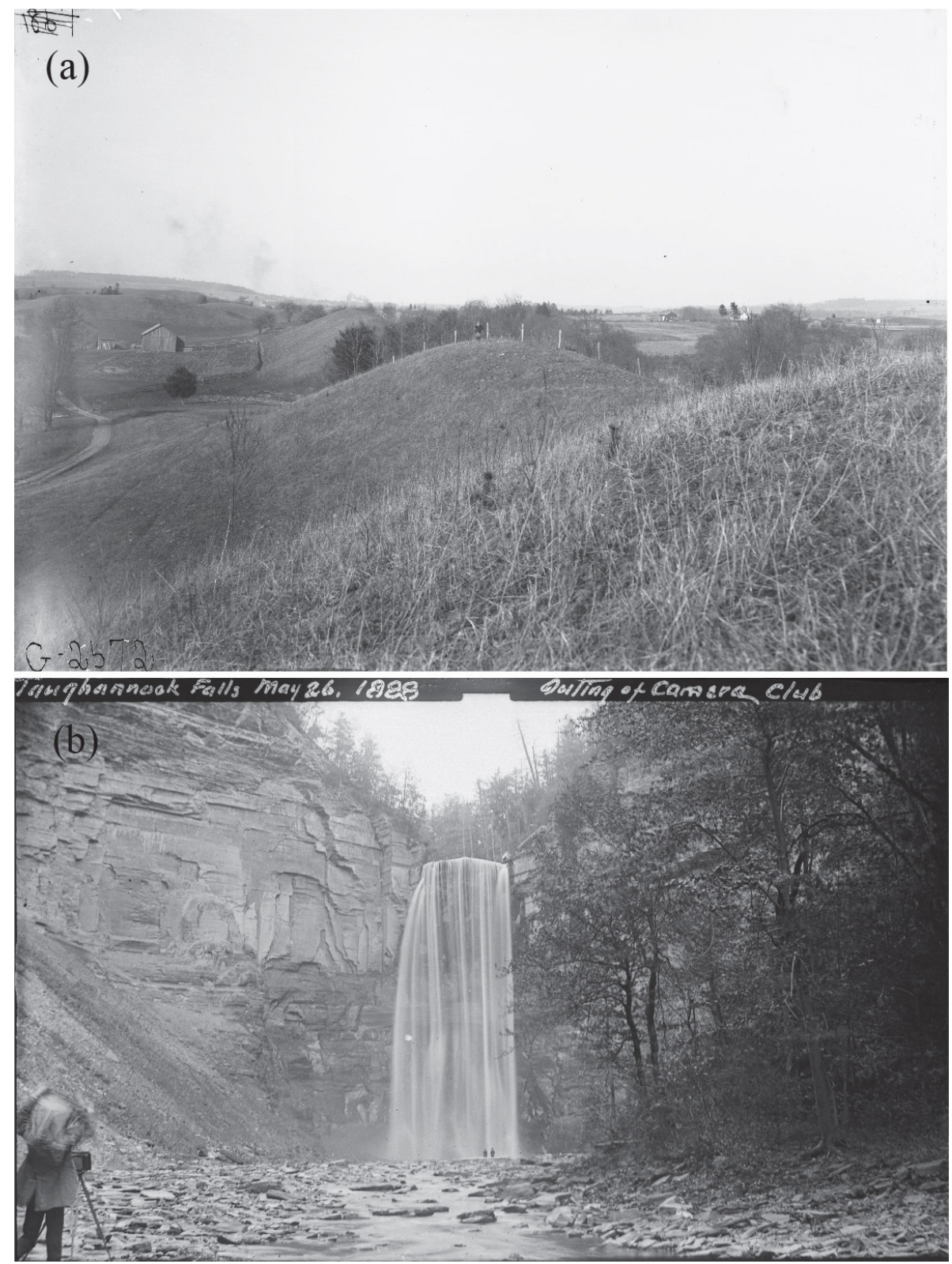

Figure 12. Digitized images from the Ithaca area. (a) Ridge of an esker, McLean, NY (ID: tve_ithaca_07). (b) Taughannock Falls in 1888 (ID: tve_ithaca_02).

Greenland (http://digital.library.cornell.edu/collections/tarr, last access: 15 March 2020). The collection includes 1948 images with metadata, has a digital object identifier (https://doi.org/10.7298/X4M61H5R, last access: 9 February 2020), and can be cited as Tarr and Cornell University Library (2014). The photographs are believed to have no known United States copyright or other restrictions. The Library does not charge for permission to use such material and does not grant or deny permission to publish or otherwise distribute public domain material in its collections. As a matter of good scholarly practice, we recommend that patrons us- ing Library-provided reproductions cite the Library, the DOI, and this article as the source of reproductions.

\subsection{Metadata and filenames}

All of the metadata for the images is compiled in Table S1 in the Supplement. For each digitized image, the assigned filename follows a specific convention: a prefix ("tve" for Tarr and von Engeln); then either the expedition year (e.g., "exp1911"), the phrase "lanternslide", or "Ithaca"; and finally the sequential photograph number. For example, the 18th photo from the 1911 Alaska expedition would have the 
filename "tve_exp1911_018.tif". For images scanned with multiple exposures, the duplicates have filenames with numerical suffixes but otherwise identical information. Most of the photographs had descriptions (titles or captions) written on the original envelopes, and these have been transcribed as the title of each digitized image. For the lantern slides, the captions were written on the slide itself instead of the envelopes. In cases in which there was no title available, the image was given the title "No Label". For a few cases where we had other knowledge of the image subject, information on the likely location of the image was added. Besides the titles, a variety of other metadata is available for the images. We were able to assign dates (either specific dates recorded on the envelopes or more general dates based on expedition diaries) to many of the images. The work type of the original image media is also recorded (film negative, glass plate, or print). For most photographs, the location or glacier name was included on the envelope or lanternslide. In the metadata, we list both a general location (e.g., Alaska, Canada, Greenland) and a more specific location (e.g., Glacier Bay) as well as the name of the glacier (if applicable). A very few of the envelopes or lantern slides included the name of the photographer - for example, several of the Greenland photographs have "(Martin)" in the title referring to J. O. Martin (discussed above), and some of the lantern slides taken from other collections have the photographer's name in the title (e.g., Reid, Haynes, Libbey). This information was retained in the title in the metadata when available. The appropriate USGS quadrangle topographic map or Natural Resources Canada topographic map for the images was assigned when available.

Beyond the metadata described above, which is listed with each image in the digital collection, additional information was compiled for some of the images. All of this information is included in Table S1, and brief descriptions of the additional fields can be found below. The lantern slides had a systematic naming convention (e.g., most images fall into the North America or glacier categories) and numbering system that was indexed in a handwritten ledger in the RMC that was used to find the slides for teaching and public presentations. In some cases, the envelope includes additional notes about the images that have not been included in the digital published metadata through the Cornell University Library. For example, some images included a letter grade for the quality of the image ( $\mathrm{A}+$ being the highest and $\mathrm{D}$ being the lowest), presumably assessed by Tarr or von Engeln. In some other images, these notes include the name of the photographer, or if the photograph is duplicated as a lantern slide set, the number of the lantern slide is given. The approximate geographic (in longitude and latitude) location of the images is also given when possible. These positions should be taken as approximate locations only; in many cases a precise location is not possible to determine without additional ground truthing. For example, some detailed descriptions of images (e.g., "NE side Russell fiord, opposite Marble Point") allow more pre- cise locations while others (e.g., "Glacier Bay") only allow general locations. We do not attempt to precisely tag which part of a particular glacier is in an image; we assign one set of coordinates for each glacier and use those coordinates as the location for each occurrence of that glacier. For images that contain multiple points of interest, we assign coordinates based on the dominant feature. Table $\mathrm{S} 1$ also includes a direct link to each image.

We have not edited the glacier names in the metadata - it is possible that some photos labeled to show a certain glacier do not actually include that glacier, and it is also possible that photos that do not include the name of a glacier could include one. In several instances, names of glaciers used by Tarr and his colleagues were either not official names or were names that were subsequently changed. In these cases, the glacier is indexed by the name used by Tarr, and the currently accepted name is listed in the tables and the Supplement. For Greenland glaciers, our choice of accepted name was guided by Bjørk et al. (2015). As noted above each image was assigned a general region (designated a region in the metadata - e.g., Canada) and a more specific area (designated a subregion in the metadata - e.g., Yukon) when possible (for some images, location information was too vague to assign a more specific area). Several issues arose while assigning place names. One concerned the fact that multiple locations (sometimes separated by significant distances) shared the same name. As an example, there were Serpentine glaciers in Prince William Sound and Yakutat Bay in Alaska. In Greenland, there are multiple Nuussuaq peninsulas and Devil's thumbs. To make accurate location designations, we relied on locations of images taken within the same time frame; publications discussing the images and expeditions; and, in a few cases, field diary entries. For these locations, we have added information to clarify which place is being referred to in the image (e.g., Nuussuaq Peninsula, Upernavik Archipelago). Another issue concerned spelling of place names. Image subjects and locations recorded by Tarr and his colleagues had variable spellings for the same place (e.g., Nugsauk, Nugssauk) that in some cases differ from the current commonly accepted spelling (e.g., Nuussauq). In the figures and tables in this paper, we include both the spelling or spellings used by Tarr as well as the current commonly accepted spelling. We did not standardize or otherwise change the spellings of the transcribed titles. For instances where a designated subregion tag contained a variably spelled name, we used the current common spelling. Image titles also contained variable spellings of other words (e.g., fjord/fiord, canyon/canon); we left the spelling as it was transcribed.

\section{Complimentary collections}

The images discussed in this paper represent a unique addition to publically accessible imagery of glaciers and glacier 
landforms in Alaska and Greenland that are not available elsewhere, but there are other collections that provide complimentary imagery and information. Along with the expeditions discussed above, Lawrence Martin went on expeditions to Alaska without Tarr in 1904 (e.g., Tarr and Martin, 1906), 1910 (Martin, 1911, 1913b), and 1913 (Martin, 1913c). Photographs and field notebooks from these trips are part of the William O. Field papers in the Alaska and Polar Regions Collections and Archives at the University of Alaska, Fairbanks. Photographic prints from Tarr and Martin's work are included in the Dora Keen Collection at the Anchorage Museum at Rasmuson Center. Thirty-five photographs from Martin's trips are part of the $\sim 24000+$ images of the National Snow and Ice Data Center's (NSIDC) Glacier Photograph Collection (https://nsidc.org/data/glacier_photo/index. html, National Snow and Ice Data Center, 2015, last access: 9 February 2020). The University of Colorado at Boulder University Libraries (https://www.colorado.edu/libraries/, last access: 9 February 2020) also have digitized versions of those 35 images and hold Martin's field notebooks from the 1904, 1905, and 1906 Alaska expeditions in the Roger G. Barry glaciology collection. The National Geographic image collection includes 22 images of Alaska taken by Oscar von Engeln. Tarr's field notebooks from the 1896 Greenland expedition are in the RMC at Cornell. The RMC also includes a hard copy of the 1896 Greenland trip diary published by Hoppin (1897) that includes Tarr's handwritten notes in the margins. Tarr's field notebook from the 1905 Alaska expedition and his field notebook and personal diary from the 1906 Alaska trip are housed at the RMC. Von Engeln's 1906 trip diary and letters to his parents are also in the RMC. Field notebooks from Tarr and von Engeln written during the 1909 Alaska expedition are at the RMC. None of these notebooks, letters, or diaries were digitized as part of this project. The NSIDC has scanned 19 pages of Tarr's field notebook from August 1909 as well as the second half of Tarr's field notebook from the 1911 Alaska expedition. In addition to the collection discussed in this paper, Cornell University previously digitized about 20 images related to Tarr and von Engeln, which are available through the Digital Collections (https://digital.library.cornell.edu/, last access: 9 February 2020) as part of the Images from the Rare Book and Manuscript Collections Oscar von Engeln holdings.

\section{Data availability}

The digitized files are available through the Cornell University Library digital collections in the collection called Historic Glacial Images of Alaska and Greenland (http://digital.library.cornell.edu/collections/tarr, last access: 15 March 2020; Cornell University, 2014) and can be cited as Tarr and Cornell University Library (2014), https://doi.org/10.7298/X4M61H5R.

\section{Conclusions}

The newly digitized dataset will have a variety of uses for researchers. The images are of scientific interest for understanding glacier dynamics and ecological change, of public policy interest for documenting possible effects of climate change, and of historic and anthropological interest for capturing daily life in remote regions at the turn of the 20th century. The glacier images provide documentation of terminus positions and ice elevation and offer the possibility of ice volume estimates. Most the glaciers featured in the digitized images have undergone significant change over the past century, and comparison of the information in the images to modern data will provide new or more robust estimates of the extent of this change.

Supplement. The supplement related to this article is available online at: https://doi.org/10.5194/essd-12-771-2020-supplement.

Author contributions. JE conceived of this project, and both JE and MP worked to collect the metadata, supervise undergraduate student workers, secure funding, interact with Cornell University Library staff to digitize the images and make them available online, and write the article.

Competing interests. The authors declare that they have no conflict of interest.

Acknowledgements. We thank all of the Cornell University Library staff who facilitated the digitization and made the data available on the web: Rhea Garen, Wendy Kozlowski, Jason Kovari, David Lurvey, Hannah Marshall, Danielle Mericle, Liz Muller, and Melissa Wallace. We thank the nine undergraduate students at Purdue University and Cornell University who helped to catalog the Tarr and von Engeln collections and create the metadata: Phoebe Dawkins, Anant Hariharan, Haydn Lenz, Alexis Lopez-Cepero, MacKenzie McAdams, Sam Nadell, Ella Noor, Emma Reed, and Frank Tian. Figures were generated with the Generic Mapping Tools software of Wessel et al. (2013). We are grateful to the late Art Bloom for making us aware of these photographs in the first place. Finally, we thank reviewers Anders Anker Bjørk and Florence Fetterer as well as Topical Editor Reinhard Drews for constructive reviews that improved the manuscript.

Financial support. Funds for digitization of the images were provided by Cornell University through the Grants Program for Digital Collections in Arts and Sciences (Principal Investigator Aaron Sachs), through the Einhorn Discovery Grant and Undergraduate Research Program of the College of Arts and Sciences (for student Emma Reed), and the Morley Research Fund from the College of Agriculture and Life Sciences (for student Sam Nadell). 
Review statement. This paper was edited by Reinhard Drews and reviewed by Anders Anker Bjørk and Florence Fetterer.

\section{References}

Alley, B.: Rivers of Ice: The Yakutat Bay Expedition of 1906, Outskirts Press, 93 pp., 2012.

Bjørk, A. A., Kjær, K. H., Korsgaard, N. J., Khan, S. A., Kjeldsen, K. K., Andresen, C. S., Box, J. E., Larsen, N. K., and Funder, S. V.: An aerial view of 80 years of climate-related glacier fluctuations in southeast Greenland, Nat. Geosci., 5, 427-432, https://doi.org/10.1038/ngeo1481, 2012.

Bjørk, A. A., Kruse, L. M., and Michaelsen, P. B.: Brief communication: Getting Greenland's glaciers right - a new data set of all official Greenlandic glacier names, The Cryosphere, 9, 22152218, https://doi.org/10.5194/tc-9-2215-2015, 2015.

Brice, W. R.: Ralph Stockman Tarr: Scientist, writer, teacher, Geol. Soc. Am., Centennial Special Volume 1, 215-235, 1985.

Brice, W. R.: Cornell Geology Through the years, College of Engineering, Cornell University, 230 pp., 1989.

Conner, C., Streveler, G., Post, A., Monteith, D., and Howell, W.: The Neoglacial landscape and human history of Glacier Bay, Glacier Bay National Park and Preserve, southeast Alaska, USA, The Holocene, 19, 381-393, 2009.

Cornell University: Digital Collections, Historic Glacial Images of Alaska and Greenland, from the Ralph Stockman Tarr expeditions (1896; 1905-1911), available at: http://digital.library. cornell.edu/collections/tarr (last access: 15 March 2020), 2014.

Gardner, A. S., Moholdt, G., Cogley, J. G., Wouters, B., Arendt, A. A., Wahr, J., Berthier, E., Hock, R., Pfeffer, W. T., Kaser, G., and Ligtenberg, S. R: A reconciled estimate of glacier contributions to sea level rise: 2003 to 2009, Science, 340, 852-857, 2013.

Hill, E. A., Carr, J. R., Stokes, C. R., and Gudmundsson, G. H.: Dynamic changes in outlet glaciers in northern Greenland from 1948 to 2015, The Cryosphere, 12, 3243-3263, https://doi.org/10.5194/tc-12-3243-2018, 2018.

Hoppin, B.: A Diary Kept While with the Peary Arctic Expedition of 1896, (New Haven: n.p.), 80 pp., 1897.

Huntington, P. A. M.: Robert E. Peary and the Cape York Meteorites, Polar Geogr., 1, 53-65, https://doi.org/10.1080/789609353, 2002.

Koelsch, W. A.: William Libbey of Princeton: A Forgotten Geographer, Middle States Geogr., 49, 1-8, 2016.

Larsen, C. F., Motyka, R. J., Arendt, A. A., Echelmeyer, K. A., and Geissler, P. E.: Glacier changes in southeast Alaska and northwest British Columbia and contribution to sea level rise, J. Geophys. Res., 112, F01007, https://doi.org/10.1029/2006JF000586, 2007.

Larsen, C. F., Burgess, E., Arendt, A. A., O’Neel, S., Johnson, A. J., and Kienholz, C.: Surface melt dominates Alaska glacier mass balance, Geophys. Res. Lett., 42, 5902-5908, https://doi.org/10.1002/2015GL064349, 2015.

Maness, J., Duerr, R., Dulock, M., Fetterer, F., Hicks, G., Merredyth, A., Sampson, W., and Wallace, A.: Revealing our melting past: Rescuing historical snow and ice data, Geophys. Res. J., 14, 92-97, https://doi.org/10.1016/j.grj.2017.10.002, 2017.

Martin, L.: Alaskan earthquakes of 1899, Bull. GSA, 21, 339-406, 1910.
Martin, L.: The National Geographic Society researches in Alaska, The Nat. Geogr. Mag., 22, 537-561, 1911.

Martin, L.: Alaskan Glaciers in Relation to Life, Bull. Am. Geographical Soc., XLV, 801-818, 1913 a.

Martin, L.: Some features of glaciers and glaciation in College Fiord, Prince William Sound, Alaska, Z. Gletscherk., 7, 289-333, $1913 b$.

Martin, L.: "Juneau-Yakutat Section", Guide Books of Excursions in Canada, No. 10. (Twelfth International Geological Congress, Toronto, 1913.) Ottawa: Canadian Geological Survey, 121-76, $1913 \mathrm{c}$.

Meier, M. and Post, A.: What are Glacier Surges?, Can. J. Earth Sci., 6, 807-817, https://doi.org/10.1139/e69-081, 1969.

Meier, M. F., Rasmussen, L. A., Krimmel, R. M., Olsen, R. W., and Frank, D.: Photogrammetric determination of surface altitude, terminus position, and ice velocity of Columbia Glacier, Alaska, U.S. Geol. Surv. Prof. Pap., 1258-F, 41 pp., 1985.

Molnia B. F.: Late nineteenth to early twenty-first century behavior of Alaskan glaciers as indicators of changing regional climate, Global Planet. Change, 56, 23-56, https://doi.org/10.1016/j.gloplacha.2006.07.011, 2007.

Molnia, B. F.: Glaciers of North America - Glaciers of Alaska, U.S. Geological Survey Professional Paper 1386-K, 2008.

National Snow and Ice Data Center (comp.): Glacier Photograph Collection, Version 1, [Indicate subset used], Boulder, Colorado USA. NSIDC: National Snow and Ice Data Center, https://doi.org/10.7265/N5/NSIDC-GPC-2009-12, 2015.

Plafker, G. and Thatcher, W.: Geological and geophysical evaluation of the mechanisms of the great 1899 Yakutat Bay earthquakes, Active Tectonics and Seismic Potential of Alaska, 215236, 2008.

Post, A.: Alaskan Glaciers: Recent Observations in Respect to the Earthquake-Advance Theory, Science, 148, 3668, 366-368, https://doi.org/10.1126/science.148.3668.366, 1965.

Post, A., O'Neel, S., Motyka, R. J., and Streveler, G.: A complex relationship between calving glaciers and climate, Eos Trans. AGU, 92, 305, 2011.

Tarr, R. S.: The Cornell Expedition to Greenland, Science, 4, 520523, 1896.

Tarr, R. S.: Former extension of Cornell Glacier near the southern end of Melville Bay, Bull. Geol. Soc. Am., 8, 251-268, pls. 2529, 1897a.

Tarr, R. S.: The margin of Cornell glacier (Greenland), Am. Geol., 20, 139-156, pls. VI-XII, 1897b.

Tarr, R. S.: Former extension of ice in Greenland, Science, 5, 804 805 (see also pg. 344), 1897c.

Tarr, R. S.: The Arctic sea ice as a geological agent, Am. J. Sci., 3, 223-229 (Also: Supplement 44, pp. 17, 941-17,942), 1897d.

Tarr, R. S.: Difference in the climate of Greenland and American sides of Davis Strait and Baffin Bay, Am. J. Sci., 3, 315-321, $1897 \mathrm{e}$.

Tarr, R. S.: Evidence of glaciation in Labrador and Baffin Land, Am. Geol., 19, 191-197, pl. X, 1897f.

Tarr, R. S.: Valley glaciers of the upper Nugusak peninsula, Greenland, Am. Geol., 19, 262-267 pl. XV, 1897g.

Tarr, R. S.: The glaciers of Greenland, Sci. Am., 76, 216-217, $1897 \mathrm{~h}$.

Tarr, R. S.: Rapidity of weathering and stream erosion in the Arctic latitudes, Am. Geologist, 19, 131-136, 1897i. 
Tarr, R. S.: Hanging valleys in the Finger Lakes region of central New York, Am. Geol. 33, 271-291, 1904.

Tarr, R. S.: Some instances of moderate glacial erosion, J. Geol., 13, 160-173, 1905a.

Tarr, R. S.: Moraines of Seneca and Cayuga Lake valleys, Bull. Geol. Soc. Am., 16, 215-228, 1905 b.

Tarr, R. S.: Drainage features of central New York, Bull. Geol. Soc. Am., 16, 229-242, 1905c.

Tarr, R. S.: The gorges and waterfalls of central New York, Am. Geog. Soc. Bull., 27, 193-212, 1905d.

Tarr, R. S.: The Yakutat Bay region, U. S. Geol. Survey, Bull. No. 284, 61-64, 1906a.

Tarr, R. S.: Glacial erosion in the Finger Lakes region of central New York, Geology, 14, 18-21, 1906b.

Tarr, R. S.: Watkins Glen and other gorges of the Finger Lakes region of central New York, Pop. Sci. Monthly, 68, 387-397, 1906c.

Tarr, R. S.: Second expedition to Yakutat Bay, Alaska, Phlla. Geog. Soc. Bull., vol. 5, No. 1, Jan., 1-14, Glacial erosion in Alaska, Pop. Sci. Mon., vol. 70, No. 2, Feb., 1007, 09-110, 1907a.

Tarr, R. S.: Glacial erosion in Alaska, Pop. Sci. Monthly, 70, 99110, 1907b.

Tarr, R. S.: Recent advance of glaciers in the Yakutat Bay region, Alaska, Bull. Geol. Soc. Am., 18, 257-286, 1907c.

Tarr, R. S.: The Malaspina Glacier, Am. Geogr. Soc. Bull., 3, $273-$ 285, 1907d.

Tarr, R. S.: The advancing Malaspina Glacier, Science, 25, 34-37, 1907e.

Tarr, R. S.: The Yakutat Bay region, Alaska. U. S. Geol. Survey, Professional Paper 64, 190, 183 pp., 1909.

Tarr, R. S.: Oscillations of Alaskan glaciers, Abstract : Science, new ser., vol. 32, Aug. 5, 185-186, Abstract and discussion, Bull. Geol. Soc. Am., 21, 758-759, 1910.

Tarr, R. S.: The theory of advance of glaciers in response to earthquake shaking, Z. Gletscherk., Band V, 1-35, 1910.

Tarr, R. S. and Cornell University Library: Historic Glacial Images of Alaska and Greenland from the Ralph Stockman Tarr expeditions (1896; 1905-1911), Cornell University Library, https://doi.org/10.7298/X4M61H5R, 2014.

Tarr, R. S. and Martin, L.: Recent change of level in Alaska, Science, 22, 879-880, 1905.

Tarr, R. S. and Martin, L.: Recent Changes of Level in the Yakutat Bay Region, Alaska, Bull. GSA, 17, 29-64, 1906a.
Tarr, R. S. and Martin, L.: Recent change of level in Alaska, Geogr. J., July, 30-43, 1906b.

Tarr, R. S. and Martin, L.: Glaciers and glaciation of Yakutat Bay, Alaska, Am. Geog. Soc. Bull., 8, 1906, 145-167, 1 plate, figs. 24, Abstract: Ibid., vol. 38, No. 2, Feb., 99-101, 1906 c.

Tarr, R. S. and Martin, L.: Position of Hubbard Glacier front in 1792 and 1794, Am. Geog. Soc. Bull., 39, 129-136, 1907.

Tarr, R. S. and Martin, L.: The National Geographic Society's Alaskan Expedition of 1909, The National Geographic Magazine, XXI, 1-53, 1910.

Tarr, R. S. and Martin, L.: The earthquakes of Yakutat Bay, Alaska in September 1899, U.S. Geol. Surv. Prof. Pap., 69, 135 pp., 1912a.

Tarr, R. S. and Martin, L.: An Effort to Control a Glacial Stream, Ann. Assoc. Am. Geogr., 2, 25-40, 1912b.

Tarr, R. S. and Martin, L.: Glacial Deposits of the Continental Type in Alaska, J. Geol., XXI, 289-300, 1913.

Tarr, R. S. and Martin, L.: Alaskan glacier studies of the National Geographic Society in the Yakutat Bay, Prince William Sound and lower Copper River regions: Washington, D.C., National Geographic Society, 498 p., 1914.

Tarr, R. S. and Cornell University Library: Historic Glacial Images of Alaska and Greenland from the Ralph Stockman Tarr expeditions (1896; 1905-1911), Cornell University Library, https://doi.org/10.7298/X4M61H5R, 2014.

von Engeln, O. D.: Some Alaskan Days - and nights: Cornell Era, Dec., 122-124, 1906

von Engeln, O. D.: An Alaskan wonderplace: Outlook, v. 86 May 25, 169-180, 1907a.

von Engeln, O. D.: The photographic equipment of a sub-arctic exploring party, Photo-Era, October, 1907b.

von Engeln, O. D.: Photography in glacial Alaska: The National Geographic Magazine, 21, 54-62, 1910.

von Engeln, O. D.: Phenomena associated with glacier drainage and wastage with especial reference to observations in the Yakutat Bay Region, Alaska, Reprinted from Zeitschrift für Gletscherkunde, Band VI, Heft 2, 1911.

Wessell, P., Smith, W. H. F., Scharroo, R., Luis, J. F., and Wobbe, F.: Generic Mapping Tools: Improved version released, EOS Trans. AGU, 94, 409-410, 2013. 